SHEs: Conference Series 3 (1) (2020) $332-338$

\title{
Village Community Resilience In Facing Pandemic Covid-19 Year 2020 (Case Study In Nayu RT 04 RW 05 Joglo Banjarsari)
}

\author{
Ika Agustina Yaniastiwi \\ Universitas Sebelas Maret \\ ikaagustina29@yahoo.com
}

\section{Article History}

accepted 31/08/2020

approved 22/09/2020

published 28/10/2020

\begin{abstract}
In Indonesia, the number of sufferers of COVID-19 has increased. This study aims to: 1) Determine the distribution moment of COVID-19 in Nayu RT 04 RW 05 Joglo Banjarsari; 2) Knowing the resilience level of the Nayu RT 04 RW 05 Joglo Banjarsari in terms of health, physical, social, economic, and spatial planning in the face of the COVID-19 pandemic. The results showed: 1) The results of moderate economic reliability were due to the fact that during the covid pandemic the economy of the residents had decreased, but because of the assistance from the government in the form of food and cash; 2) The results of resilience in the health sector are high because the public pays more attention to the covid protocol and maintains more cleanliness.
\end{abstract}

Keywords: Pandemic, COVID, Resilience.

\section{Abstrak}

Di Indonesia, jumlah penderita COVID-19 semakin bertambah. Penelitian ini bertujuan untuk : 1) Mengetahui moment distribusi COVID-19 di Nayu RT 04 RW 05 Joglo Banjarsari; 2) Mengetahui tingkat resiliensi masyarakat Nayu RT 04 RW 05 Joglo Banjarsari ditinjau dari segi kesehatan, fisik, sosial, ekonomi, dan tata ruang dalam menghadapi pandemi COVID-19. Hasil penelitian menunjukkan: 1) Hasil reliensi ekonomi sedang karena walaupun di waktu pandemi covid ini ekonomi warga berkurang tetapi karena adanya bantuan dari pemerintah berupa sembako dan uang tunai; 2) hasil resiliensi dibidang kesehatan tinggi karena masyarakat lebih memperhatikan protokol covid dan lebih menjaga kebersihan.

Kata kunci: Pandemi, COVID, Resiliensi. 
SHEs: Conference Series 3 (1) (2020) $332-338$

\section{PENDAHULUAN}

Coronavirus Disease-2019 (COVID-19) adalah penyakit menular yang disebabkan oleh Severe Acute Respiratory Syndrome Coronavirus 2 (SARS- COV2) yang termasuk dalam keluarga besar coronavirus yang ditemukan pada manusia sejak kejadian luar biasa muncul di Wuhan Cina, pada Desember 2019. Penyebab penyakit yang satu ini sama dengan penyebab SARS pada tahun 2003, hanya berbeda jenis virusnya, karena COVID-19 memiliki penyebaran yang lebih luas dan cepat ke beberapa negara dibanding SARS (WHO, 2019).

Terdapat beragam prediksi terkait kapan masa puncak dan pandemi COVID-19 akan berakhir di Indonesia, diantaranya yaitu prediksi dari UGM yang menyataka bahwa masa puncak COVID-19 di Indonesia adalah 7-11 April 2020 dan akan berakhir pada 29 Mei 2020. Akan tetapi, ternyata hingga saat ini kasus COVID-19 belum menunjukkan tanda-tanda akan berakhir. Prediksi lain dari Singapore University of Technology and Design yang menyataka bahwa masa puncak COVID19 di Indonesia adalah 20 April 2020 dan akan berakhir pada 7 Oktober 2020 (katadata, 2020). Perkembangan kasus terbaru di Indonesia, berdasarkan pemaparan dari Juru Bicara Pemerintah untuk Penanganan COVID-19 Achmad Yurianto (2020) per 30 Mei 2020, sebanyak 25.773 orang positif; 17.185 dirawat; 7.015 sembuh; dan 1.573 mmeninggal dunia (nasional.kompas.com, 2020), dengan sebaran kasus baru terbanyak berada di Provinsi Jawa Timur.

Kang et al. (2007) mendefinisikan resiliensi sebagai kemampuan sistem untuk pulih setelah bahaya terjadi dan mengukur resiliensi berdasarkan durasi kondisi yang tidak memuaskan. Secara lebih sederhana, Keye \& Pidgeon (2013) mendefinisikan resiliensi sebagai kemampuan untuk "mempertahankan stabilitas psikologis dalam menghadapi stres". Selanjutnya (Rojas F., 2015) menyatakan resiliensi sebagai kemampuan menghadapi tantangan, resiliensi akan tampak ketika seseorang menghadapi pengalaman yang sulit dan tahu bagaimana menghadapi atau beradaptasi dengannya (Utami, 2017). Kapasitas Resiliensi merupakan kemampuan orang, rumah tangga, komunitas, dan lembaga untuk mempersiapkan, merespons, dan pulih dari guncangan dan tekanan. Kemampuan ini didorong oleh kapasitas resiliensi, atau sumber- sumber resiliensi yang memungkinkan perlindungan dan peningkatan kesejahteraan.

Resiliensi itu sendiri secara luas bisa diartikan sebagai kemampuan untuk mengatasi dengan baik perubahan hidup pada level yang tinggi, menjaga kesehatan di bawah kondisi penuh tekanan, bangkit dari keterpurukan, mengatasi kemalangan, merubah cara hidup ketika cara yang lama dirasa tidak sesuai lagi dengan kondisi yang ada, dan menghadapi permasalahan tanpa melakukan kekerasan (Siebert, 2005). Untuk mengetahui tingkat resiliensi masyarakat Nayu dalam menghadapi pandemi COVID-19, perlu diketahui bagaimana kondisi kesehatan, kondisi fisik wilayah, kondisi sosial dan ekonomi, kondisi tata ruang, serta kebijakan-kebijakan apa saja yang telah ditetapkan oleh aparat kampung nayu. Masing-masing kondisi tersebut dapat diketahui melalui serangkaian indikator yang nantinya dapat diakumulasikan untuk mengetahui apakah masyarakat kampung nayu termasuk memiliki resiliensi yang rendah, sedang, atau tinggi. Peran kampung Nayu dalam menangani COVID-19 termasuk tinggi.

Daerah nayu merupakan salah satu daerah yang ada di Kecamatan Banjarsari, Kota Surakarta. Meskipun hingga saat ini, tidak ada catatan medis yang menyatakan adanya pasien COVID-19 di daerah Nayu, tapi masyarakat Nayu pun turut merasakan dampak tak langsung yang ditimbulkan oleh COVID-19, karena harus menyesuaikan segala aktivitasnya dalam berbagai bidang sesuai dengan arahan dan protokol 
SHEs: Conference Series 3 (1) (2020) $332-338$

kesehatan yang telah ditetapkan oleh pemerintah pusat. Berkaca dari momen-momen penting terkait kasus perkembangan COVID- 19 dalam skala nasional. Dikampung nayu RT 04 RW 05 Joglo Banjarsari pun turut merasakan momen tersebut tapi dengan kondisi yang berbeda, begitu pula kampung-kampung yang ada di wilayah lainnya, karena perkembangan kasus di tiap-tiap wilayah berbeda. Hal itu tentunya dipengaruhi oleh beragam faktor, terutama adalah faktor masyarakat yang ada di wilayah yang bersangkutan. Momen-momen itulah yang nantinya dapat menggambarkan siklus adaptif masyarakat kampung Nayu dalam menghadapi COVID-19 yang terbagi ke dalam beberapa tahapan sebagaimana proses dalam Teori Panarchy. Hal itu menjadi penting untuk diketahui karena baik kampung yang terdampak, maupun kampung yang tidak terdampak seperti Nayu RT 04 RW 05, masyarakatnya diharapkan memiliki tingkat resiliensi (Holling, 1973) atau daya lenting yang tinggi dalam menghadapai pandemi COVID-19, terutama dalam menyongsong New Normal Era

Sebagaimana Pasal 5 Permen Desa PDDT Nomor 11 Tahun 2019 tentang Prioritas Penggunaan Dana Desa Tahun 2020 adalah bidang Pembangunan Desa dan Pemberdayaan Masyarakat Desa, meliputi: Peningkatan kualitas hidup; Peningkatan kesejahteraan; Penanggulangan kemiskinan; dan Peningkatan pelayanan publik. Kegiatan peningkatan pelayanan publik diutamakan untuk membiayai pelaksanaan program bidang kesehatan, pendidikan dan sosial, sedangkan peningkatan kualitas hidup masyarakat desa diutamakan untuk membiayai pelaksanaan program dan kegiatan di bidang pelayanan sosial dasar yang berdampak langsung pada meningkatnya kualitas hidup masyarakat seperti pengadaan, pembangunan, pengembangan, serta pemeliharaan sarana dan prasarana lingkungan alam untuk kesiapsiagaan menghadapi bencana alam; penanganan bencana alam.

Beberapa langkah yang dapat diambil RW dalam rangka menghadapi pandemic COVID-19 adalah sebagai berikut: membentuk satgas siaga COVID-19 tingkat Rukun Warga (RW) struktur tugas: Ketua Satgas Koordinator Kesehatan, Koordinator Keamanan, Koordinator Logistik, Humas Tugas dan fungsi satgas: penanggung jawab siaga Covid-19 tingkat RW/Kampung, mengedukasi warga tentang Covid-19, menggerakkan partisipasi warga untuk siaga Covid-19, membuat sistim keamanan warga, membuat sistem informasi keamanan warga pengecekan kesehatan warga. Membersihkan fasilitas umum dan fasilitas sosial secara berkala. Menutup sementara area publik untuk menghindari berkumpulnya warga. Menghimbau warga untuk tidak melakukan aktifitas yang melibatkan banyak orang, seperti arisan, festival, perlombaan dan lain-lain. Penyediaan hand sanitizer di sekolah dan tempat ibadah. Mengaktifkan sistem keamanan warga. Wajib lapor 1x24 jam bagi tamu (bukan warga tetap). Cek kesehatan setiap tamu yang datang. Himbau warga untuk sementara tidak menerima tamu. Himbau warga untuk menggunakan alat makan dari rumah jika membeli makanan dari pedagang keliling. Himbau para pedagang makanan keliling untuk menggunakan masker dan sarung tangan saat melayani pelanggan.

Berdasarkan latar belakang tersebut, maka rumusan masalah dalam penelitian Kuliah Kerja Lapangan (KKL) ini, antara lain: (1) Bagaimana momen penyebaran COVID-19 di kampung Nayu RT 04 RW 05 Joglo Banjarsari? dan, (2) Bagaimana tingkat resiliensi masyarakat Nayu RT 04 RW 05 Joglo Banjarsari ditinjau dari segi kesehatan, fisik, sosial, ekonomi, dan tata ruang dalam menghadapi pandemi COVID19 ? Berdasarkan rumusan masalah tersebut, maka tujuan dalam penelitian Kuliah Kerja Lapangan (KKL) ini, antara lain: (1) Mengetahui momen distribusi COVID-19 di Nayu RT 04 RW 05 Joglo Banjarsari. (2) Mengetahui tingkat resiliensi masyarakat Nayu RT 04 RW 05 Joglo Banjarsari ditinjau dari segi kesehatan, fisik, sosial, 
SHEs: Conference Series 3 (1) (2020) $332-338$

ekonomi, dan tata ruang dalam menghadapi pandemi COVID-19. Penelitian ini diharapkan berguna bagi pemerintah daerah setempat sebagai bahan masukan atau pertimbangan untuk membuat kebijakan dalam meminimalisasi penyebaran COVID19.

\section{METODE PENELITIAN}

Metode yang digunakan dalam penelitian ini adalah deskriptif kualitatif. Teknik pengambilan sampel yang digunakan dalam penelitian ini adalah dengan cara: (1) Purposive sampling, dalam penelitian ini digunakan untuk wawancara semi terstruktur kepada Pengurus PKK Kampung Nayu, Instansi Kesehatan (Puskesmas), Ketua RT. (b) Accidental sampling, dalam penelitian ini digunakan untuk wawancara semi terstruktur kepada masyarakat kampung Nayu yang pada saat pengambilan sampel berlangsung sedang berada di lokasi penelitian.

Data Primer pada penelitian ini yaitu: data momen penyebaran COVID-19 di Nayu, data kondisi kesehatan, data kondisi fisik kampung, data kondisi sosial masyarakat Nayu, data kondisi ekonomi warga Kampung Nayu, data kondisi tata ruang Kampung Nayu, data kebijakan yang diberlakukan aparat desa selama pandemi COVID- 19, data kapasitas resiliensi. Data sekunder: data demografis masyarakat Kampung Nayu, data hasil pencatatan penduduk/non-penduduk yang masuk ke Ketua RT selama masa pandemi COVID-19.

Uji validitas dalam penelitian ini menggunakan triangulasi teknik dan triangulasi sumber data. Untuk menjawab tujuan penelitian menggunakan observasi untuk mengetahui momen persebaran covid dan wawancara semi terstruktur untuk mengetahui resiliensi masyarakat di Kampung Nayu.

\section{HASIL PENELITIAN DAN PEMBAHASAN}

1. Momen Penyebaran COVID-19 Di Kampung Nayu RT 04 RW 05 Joglo Banjarsari

Wilayah kampung Nayu adalah pemukiman yang padat penduduk, dengan bentuk rumah berjajar dan berpagar. Sehingga untuk bersosialisasi antar warga satu dengan warga yang lain kurang begitu akrab. Momen persebaran covid-19 dari awal tahap sampai akhir hampir tidak ada yang terkena atau positif covid19, karena wilayah kampung nayu merupakan zona hijau. Meskipun begitu tetap ada pembatasan dalam bidang ekonomi dan pendidikan dikarenakan warga beramai-ramai mengikuti anjuran Pemkot Surakarta dan Pemerintah Pusat untuk menerapkan protokol kesehatan dan pembatasan untuk menghindari menyebarluasnya virus covid-19.

\section{Tingkat Resiliensi Masyarakat Nayu RT 04 RW 05 Joglo Banjarsari}

Hasil penelitian ini menunjukkan bahwa resiliensi masyarakat Kampung Nayu, RT 04 RW 05 termasuk tinggi. Semua data hasil penelitian ini diuraikan berdasarkan fokus pertanyaan penelitian sebagai berikut :

(1) Kesehatan, Nayu RT 04 RW 05 dekat dengan pusat kesehatan masyarakat (PUSKESMAS) sehingga dalam mengatasi warga yang terganggu kesehatannya cepat mendapat penanganan, tentunya sesuai dengan standar penanganan protokol COVID-19. Dalam kasus corona virus ini, dikampung Nayu RT 04 RW 05 tidak ada orang dalam pengawasan (ODP) ataupun pasien dalam pengawasan (PDP), dan wilayah kampung nayu bukan termasuk dalam zona merah. Tapi warga masyarakatnya taat terhadap aturan yang ditetapkan pemerintah, karena himbauan bermasker dan cuci tangan sehingga setiap rumah pasti menyediakan tempat cuci tangan didepan rumahnya. Penyemprotan disinfektan pun dilakukan disemua rumah warga tidak 
SHEs: Conference Series 3 (1) (2020) $332-338$

terkecuali.

(2) Fisik, kondisi fisik Kampung Nayu adalah wilayah perkotaan. Untuk ketersediaan air bersih masih terjangkau dengan penggunaan PDAM ataupun sumur yang dibuat oleh masyarakat kampung nayu. Disekitar nayu praktis tidak ada area persawahan. Nayu sendiri terletak ditopografi yang relatif datar sehingga keberadaan air bersih tidak menjadi permasalahan yang pokok.

(3) Sosial, penduduk yang berada di wilayah nayu lebih banyak anak-anak, dewasa dan orang tua, keberadaan remaja lebih sedikit. Pendidikan warganya rata-rata $\mathrm{S1}$, banyak dari warga RT 04 yang berprofesi sebagai guru. Untuk tempat ibadah tersebar merata bahkan dalam RT 04 ini terdapat 1 masjid, 1 gereja dan 1 vihara, jadi untuk warganya relatif merata agamanya.

(4) Ekonomi, warga dari RT 04 tidak ada yang terkena corona virus, tetapi dampak ekonomi dari adanya lockdown yaitu kebijakan yang dikeluarkan pemerintah ternyata mempunyai dampak yang sangat tinggi. Masyarakat yang tadinya mempunyai pekerjaan wirausaha atau berdagang menjadi sepi karena aktivitas masyarakat dibatasi dan tidak boleh ada pergerakan massa yang banyak. Sedangkan yang menjadi karyawan banyak yang dirumahkan karena perusahaan tidak lagi mampu untuk membayar karyawan. Ada beberapa warga yang berkurang pendapatannya, padahal sebelum corona virus masih bisa memenuhi kebutuhannya karena lebih tapi sekarang hidup apa adanya.

(5) Tata Ruang, Kampung Nayu mempunyai tata ruang perkotaan yang rapat dan padat penduduknya. Bentukan mirip dengan perumahan sehingga jarak tetangga satu dan yang lainnya saling berimpitan, ada ruang terbuka berupa taman cerdas untuk anak-anak bermain. Tapi walaupun padat penduduknya satu sama lain jarang kontak langsung dikarenakan kesibukan masing-masing warganya.

(6) Kebijakan, Kebijakan yang diambil pemerintah dalam kondisi covid ini sangat banyak diantaranya ada:

(a) Sosial Distancing, warga menaatinya dengan cara buka tutup warung bagi yang berdagang dengan jam yang sudah ditetapkan pemerintah, dengan menyediakan tempat cuci tangan dan sabun. lbu-ibu PKK atau pun bapak-bapak selama pandemi ini tidak diperkenankan untuk mengadakan yang bertujuan untuk mengumpulkan massa sehingga untuk sementara waktu ditiadakan. Bagi warga yang beribadah ke mesjid harus dengan protokoler covid yaitu jaga jarak dan memakai masker.

(b) Karantina, kegiatan karantina bagi yang pulang dari wilayah zona merah juga dilakukan oleh pihak RT di nayu, karantina ini dilakukan dirumah masing-masing dalam jangka waktu 14 hari.

(c) Pemberian bantuan, kebijakan pemerintah dalam pemberian bantuan dalam masa pandemi COVID ini ditujukan kepada masyarakat yang kurang mampuatau GAKIN atau keluarga miskin, untuk masyarakat yang PNS dan dianggap mampu tidak mendapatkan bantuan ini. Bantuan ini turun sudah tiga kali baik berupa sembako atau yang berupa uang, sudah terarah kepada orang yang benar-benar membutuhkan, sehingga bisa mengurangi beban masyarakat yang memang benar-benar membutuhkan. 
SHEs: Conference Series 3 (1) (2020) $332-338$

\section{KESIMPULAN}

1. Momen persebaran di Kampung Nayu RT 04 RW 05 sama seperti daerah lainnya, dikarenakan warga Kampung Nayu mengikuti protokol yang ditetapkan oleh Pemerintah meskipun tidak ada kasus positif Covid-19. Tetap ada pembatasan dalam bidang ekonomi dan pendidikan.

2. Berdasarkan data yang ada secara kesehatan, kondisi fisik, sosial, ekonomi, tata ruang dan kebijakan resiliensi dikampung nayu ini digolongkan kedalam resiliensi tinggi karena masyarakatnya tetap beraktivitas seperti biasa tetapi tetap memperhatikan himbauan dan aturan yang telah diterapkan oleh pemerintah. Diharapkan masyarakat selalu mematuhi peraturan pemerintah dengan protokol kesehatan yang lebih ketat, untuk mencegah berkembangnya virus yang dari hari kehari bertambah jumlahnya karena banyak masyarakat yang mengabaikan protokol kesehatan. Kebijakan pemerintah dalam pemberian bantuan dalam masa pandemi COVID-19 ini ditujukan kepada masyarakat yang kurang mampuatau GAKIN atau keluarga miskin, untuk masyarakat yang PNS dan dianggap mampu tidak mendapatkan bantuan ini. Bantuan ini turun sudah tiga kali baik berupa sembako atau yang berupa uang, sudah terarah kepada orang yang benar-benar membutuhkan, sehingga bisa mengurangi beban masyarakat yang memang benar-benar membutuhkan

\section{DAFTAR PUSTAKA}

Ariviyanti, N dan Wisnu P. (2014). Faktor-Faktor Yang Meningkatkan Resiliensi Masyarakat Dalam Menghadapi Bencana Rob Di Kelurahan Tanjung Emas Semarang. Jurnal Teknik PWK Volume 3 Nomor 4 2014. http://ejournals1.undip.ac.id/index.php/pwk

Cutter, S. L., Burton, C. G., \& Emrich, C. T. (2010). Disaster Resilience Indicators for Benchmarking Baseline Conditions. Journal of Homeland Security and Emergency Management, 7(1). https://doi.org/10.2202/1547- 7355.1732

Dwiartama, A. (2016). Membangun Kerangka Teoritis Untuk Memahami Resiliensi Sistempertanian-Pangan Di Indonesia. Makalah Diskusi di Lembaga Penelitian Sosial AKATIGA. https://dwiartama.files.wordpress.com/2016/08/makalah_angga_akatiga.pd $f$

Gorbalenya AE. (2020). Severe Acute Respiratory Syndrome-Related Coronavirus The Species And Its Viruses, A Statement Of The Coronavirus Study Group. bioRxiv. doi:10.1101/2020.02.07.937862

Holling, C. S. (1973). Resilience and Stability of Ecological Systems. Annu.Rev.Ecol.Syst., 4, 1-23. doi:10.1146/annurev.es.04.110173.000245

Horne JF, Orr JE (1998) Assessing behaviors that create resilient organizations. Employment Relations Today 24(4): 29-39. https://doi.org/10.1002/ert.3910240405

Keye, M. D., \& Pidgeon, A. M. (2013). Investigation of the Relationship between Resilience, Mindfulness, and Academic Self-Efficacy. Open Journal of Social Sciences, 01(06), 1-4. https://doi.org/10.4236/jss.2013.16001

Letko et al. (2020). Functional assessment of cell entry and receptor usage for SARSCoV-2 and other lineage B betacoronaviruses. Nature Microbiology: 1-8. doi:10.1038/s41564-020-0688-y

Rojas F., L. F. (2015). Factors Affecting Academic Resilience in Middle School Students: A Case Study. GiST Education and Learning Research Journal, 11(11), 63-78. https://doi.org/10.26817/16925777.286

Safrizal, dkk. (2020). Pedoman Umum Menghadapi Pandemi COVID-19 Bagi 
SHEs: Conference Series 3 (1) (2020) $332-338$

Pemerintah Daerah. Tim Krja Kementrian Dalam Negeri Untuk Dukungan Gugus Tugas COVID-19.

Utami, C. T. (2017). Self-Efficacy dan Resiliensi: Sebuah Tinjauan Meta- Analisis. Buletin Psikologi, 25(1), 54-65.

https://doi.org/10.22146/buletinpsikologi.1841 